Mahakam Nursing Journal Vol 2, No. 4, November 2018 : 141-150

ARTIKEL PENELITIAN

\title{
PENGARUH EDUKASI BERBASIS SELF CARE TERHADAP TINGKAT KELELAHAN PASIEN CHRONIC KIDNEY DISEASE
}

\author{
Elfina Natalia \\ STIKes Dirgahayu Samarinda Jl. Pasundan No.21, Kelurahan Jawa Samarinda \\ elfina.natalia@gmail.com
}

\begin{abstract}
Chronic Kidney Desease was a progressive and irreversible kidney function disorder, usually treated with hemodialysis, a frequent complaint in hemodialysis patients is fatigue. The aim of this study was to see the effect of Based Self Care Education On level fatigue in Patient With Chronic Kidney Desease during Hemodialysis. The research was a quantitative study with quasiexperimental with control group pre test-post test design was used in this studi. The study was conducted at RSUD A. Wahab Sjahranie during May to June 2017. The total samples of 111 patients hemodialysis selected by purposive sampling. The subjects was divided into the interventions group consist of 83 patient who were given based self care education and the control group 28 patients. The results of the research were obtained after 6 weeks intervention, the NonParametric Test showed that Asymp Sig (2 tailed) $=.00$ or $p$-value $<.05$ the difference fatigue level between the intervention group to the control group, Odd Ratio was showed that self care-based education intervention group has a tendency to experience fatigue change rate of 1.22 times greater than control group. The ordinal logistic analyse result was showed that $p=.00$ or $p$-value $<.05$ there was a significant effected of Based Self Care Education intervention given to changes in fatigue. Conclusions of Based Self Care Education research have an influenced on decreased fatigue. The study has been recommended on intervention could be applied as one of the education given to patients during hemodialysis therapy.
\end{abstract}

Keyword: Based Self Care Education, Fatigue, Hemodialysis

\begin{abstract}
Abstrak
Chronic Kidney Disease merupakan gangguan fungsi ginjal yang progresif dan ireversibel, salah satu penanganannya dengan hemodialisa, keluhan yang sering pada pasien hemodialisa adalah kelelahan. Tujuan penelitian ini melihat pengaruh edukasi berbasis self care terhadap perubahan tingkat kelelahan pada pasien hemodialisa, merupakan penelitian kuantitatif dengan metode kuasi eksperimen pre post test design di RSUD A. Wahab Sjahranie periode Mei-Juni 2017, pengambilan sampel dilakukan dengan cara purposive samplingmelibatkan 111 responden yang dibagi menjadi 2 kelompok intervensiedukasi berbasis self care 83 orang dan kelompok kontrol 28 orang. Hasil penelitian ini didapatkan setelah dilakukan intervensi selama 6 minggu, Uji Beda Berpasangan Non Parametrik Independent menunjukan bahwa nilai Asymp Sig (2 tailed) $=0,000$ atau $p$-value $<0,05$ ada pebedaan tingkat kelelahan antara kelompok intervensi terhadap kelompok kontrol, nilai OR menunjukkan kelompok intervensi edukasi berbasis self care memiliki kecenderungan mengalami perubahan tingkat kelelahan 1,22kali lebih besar dibandingkan dengan kelompok kontrol. Pada analisis uji logistik ordinal hasil menunjukkan nilai $p=0,00$ atau $p$-value $<0,05$ ada pengaruh yang signifikan intervensi edukasi berbasis self care yang diberikan terhadap perubahan tingkat kelelahan. Simpulan penelitian edukasi berbasis self care mempunyai pengaruh terhadap perubahan tingkat kelelahan dan direkomendasikan intervensi ini dapat diaplikasikan sebagai salah satu edukasi yang diberikan pada pasien menjalani hemodialisa.
\end{abstract}

Kata kunci : Edukasi berbasis self care, hemodialisa, kelelahan. 
Mahakam Nursing Journal Vol 2, No. 4, November 2018 : 141-150

\section{PENDAHULUAN}

Perubahan gaya hidup menyebabkan terjadi pergeseran penyakit yaitu dari penyakit menular menjadi penyakit tidak menular, saat ini menjadi perhatian khusus dunia terutama World Health Organization (WHO) karena menyebabkan kematian utama dan kecacatan. Salah satu yang saat ini cukup menjadi perhatian adalah Chronic Kidney Desease(CKD) yaituadanya gangguan pada fungsi ginjal yang progresif dan ireversibel, dimana kemampuan tubuh gagal untuk mempertahankan metabolisme serta keseimbangan cairan dan elektrolit sehingga menyebabkan uremia, yang kemudian berkembang menjadi End Stage Renal Disease (ESRD) sehingga diperlukan hemodialisa untuk kelangsungan hidup pasien.

\section{World Health Organization (WHO)} menyebutkan pertumbuhan jumlah penderita gagal ginjal di dunia pada tahun 2013 telah meningkat $50 \%$ dari tahun sebelumnya, di Amerika Serikat kejadian dan prevalensi gagal ginjal meningkat 50\% di tahun 2014 (WHO, 2014). Di Indonesia jumlah penderita CKD sekitar 150 ribu orang (Ismail et al., 2014), terjadi peningkatan pasien yang baru menjalani hemodialisa di tahun 2011 ke tahun 2012, sehingga secara keseluruhan terdapat 19.621 pasien (RisKesDas, 2013). Kalimantan Timur khususnya RSUD A. Wahab Sjahranie Samarinda dan RS Dirgahayu, dari data rekam medis tercatat pasien yang menjalani hemodialisa mulai bulan Februari - Mei 2017 berjumlah 470 pasien, dari hasil wawancara yang dilakukan peneliti pada pasien dalam setiap kunjungan ada sekitar 15-20 pasien yang mengalami kelelahan.

Salah satu treatment dalam menangani CKD yaitu hemodialisa (Corwin, 2009). Prosedur ini idealnya dilakukan selama 10-15 jam per-minggu, namun karena waktu yang dibutuhkan terlalu lama, sehingga hemodialisa sering dilakukan selama 4-5 jam dengan frekuensi 2 kali seminggu pada interval 2 hari diantara hemodialisa, kondisi ini yang merupakan stressor fisik mempengaruhi pada berbagai dimensi kehidupan pasien, keluhan yang nampak adalah kelelahan, hal ini yang mengakibatkan perubahan kualitas hidup pada pasien (Raju \& Latha, 2012).

Komplikasi yang dialami baik secara fisik maupun psikis tentunya menjadi gangguan dalam melakukan perawatan diri secara mandiri pada pasien CKD yang menjalani hemodialisa. Peran perawat sebagai seorang educator dan counselor bagi pasien menurut Orem (Tomey dan Alligood, 2014) mempunyai tanggung jawab dalam mempersiapkan kemampuan pasien dalam perawatan diri, baik kemampuan dalam menjalankan terapi dan kemampuan dalam beraktifitas serta mengontrol hidupnya pasca menjalani perawatan.

Program edukasi telah banyak dilakukan namum belum banyak yang melakukan edukasi berbasis self care terhadap tingkat 
Mahakam Nursing Journal Vol 2, No. 4, November 2018 : 141-150

kelelahan pasien CKD yang menjalani hemodialisa, hal ini yang melatarbelakangi penelitian ini.

\section{METODE PENELITIAN}

Penelitian ini menggunakan metode kuantitatif dengan quasi eksperimental design melalui pendekatan pre-test dan post-test control group. Subjek dalam penelitian ini berjumlah 111 responden dengan metode purposive sampling. Jumlah kelompok intervensi 83 responden dan kelompok kontrol 28 responden. Penelitian ini dilakukan di Unit Hemodialisa di RSUD A. Wahab Sjahranie Samarinda. Pengumpulan data penelitian dilakukan pada tanggal 18 mei sampai dengan 23 Juni 2017. Instrumen pengumpul data terdiri dari kuesioner Kuesioner Facit Fatigue Scale untuk mengevaluasi tingkat kelelahan pasien dengan penyakit kronis. Analisis data dibantu dengan menggunakan software SPSS 23.

\section{HASIL PENELITIAN DAN}

\section{PEMBAHASAN}

\section{Analisa Univariat}

Tabel 1. Hasil analisa Uji Univariat berdasarkan kelompok karakteristik responden

\begin{tabular}{lrr}
\hline \multicolumn{1}{c}{ Kelompok } & \multicolumn{2}{c}{ Total } \\
& \multicolumn{1}{c}{ n } & \% \\
\hline $18-35$ tahun & 17 & 15,3 \\
36 - 45 tahun & 24 & 21,5 \\
46 - 55 tahun & 45 & 40,5 \\
56 - 65 tahun & 21 & 18,9 \\
$>65$ tahun & 4 & 3,6 \\
& & \\
Laki-laki & 48 & 43,2 \\
Perempuan & 63 & 56,8 \\
& & \\
Swasta & 35 & 31,5 \\
Pensiun & 16 & 14,4
\end{tabular}

\begin{tabular}{lll}
\multicolumn{1}{c}{ Kelompok } & \multicolumn{2}{c}{ Total } \\
& \multicolumn{1}{c}{ n } & \% \\
\hline PNS & 12 & 10,8 \\
TNI & 1 & 9 \\
Tidak bekerja & 47 & 42,3 \\
& & \\
SD dan SMP/sederajat & 29 & 26,1 \\
SMA/sederajat & 65 & 58,6 \\
$\begin{array}{l}\text { Perguruan Tinggi } \\
\text { (Diploma, Sarjana, }\end{array}$ & 17 & 18,3 \\
Pascasarjana) & & \\
& & \\
Kelelahan Berat & 105 & 94,6 \\
Kelelahan Ringan & 6 & 5,4 \\
\hline
\end{tabular}

\section{Analisa Bivariat}

Tabel 2. Hasil Analisis Uji Beda berpasangan Kelelahan

\begin{tabular}{lccccc}
\hline \multicolumn{1}{c}{$\begin{array}{c}\text { Variabel } \\
\text { Dependen }\end{array}$} & \multicolumn{2}{c}{ Pre-test } & \multicolumn{2}{c}{ Post-test } & \multirow{2}{*}{ P-value } \\
\hline Tingkat Kelelahan & & $\%$ & N & $\%$ & \\
1 Kelelahan Berat & 83 & 100 & 13 & 15,7 & 0,00 \\
2 Kelelahan Ringan & 0 & 0 & 70 & 84,3 & \\
\hline
\end{tabular}

Tabel 3. Uji Beda Independen Kelelahan

\begin{tabular}{|c|c|c|c|c|c|}
\hline \multirow[t]{2}{*}{ Variabel Dependen } & \multicolumn{2}{|c|}{$\begin{array}{l}\text { Intervensi } \\
\text { Edukasi } \\
\text { Self Care }\end{array}$} & \multicolumn{2}{|c|}{ Kontrol } & \multirow{2}{*}{$\begin{array}{l}\mathrm{P}- \\
\text { val } \\
\text { ue }\end{array}$} \\
\hline & n & $\%$ & $\mathbf{N}$ & $\%$ & \\
\hline \multicolumn{6}{|l|}{ Tingkat Kelelahan } \\
\hline 1 Kelelahan Berat & 13 & 15,7 & 24 & 85,7 & 0,00 \\
\hline 2 Kelelahan Ringan & 70 & 84,3 & 4 & 14,3 & \\
\hline
\end{tabular}

\section{Analisa Multivariat}

Tabel 4. Hasil analisa Multivariat Tingkat Kelelahan

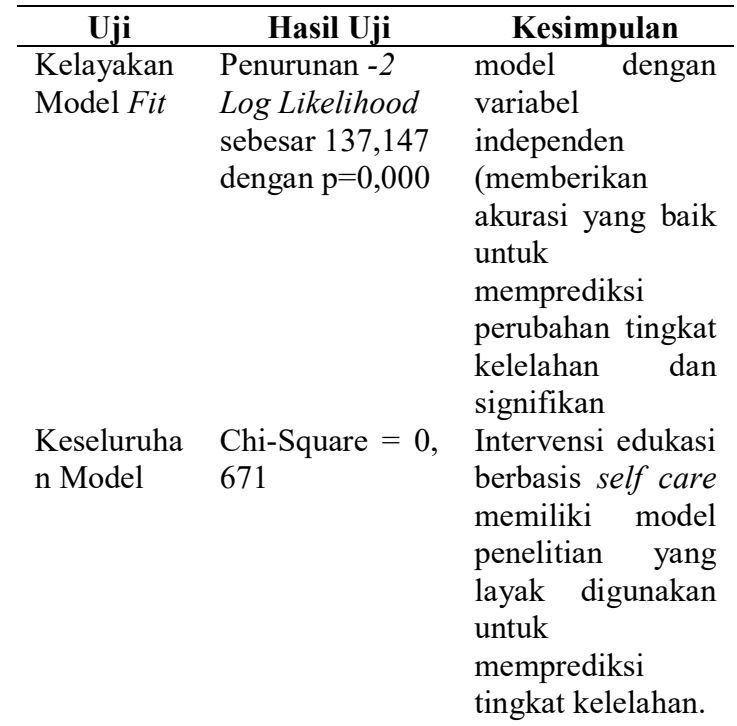


Mahakam Nursing Journal Vol 2, No. 4, November 2018 : 141-150

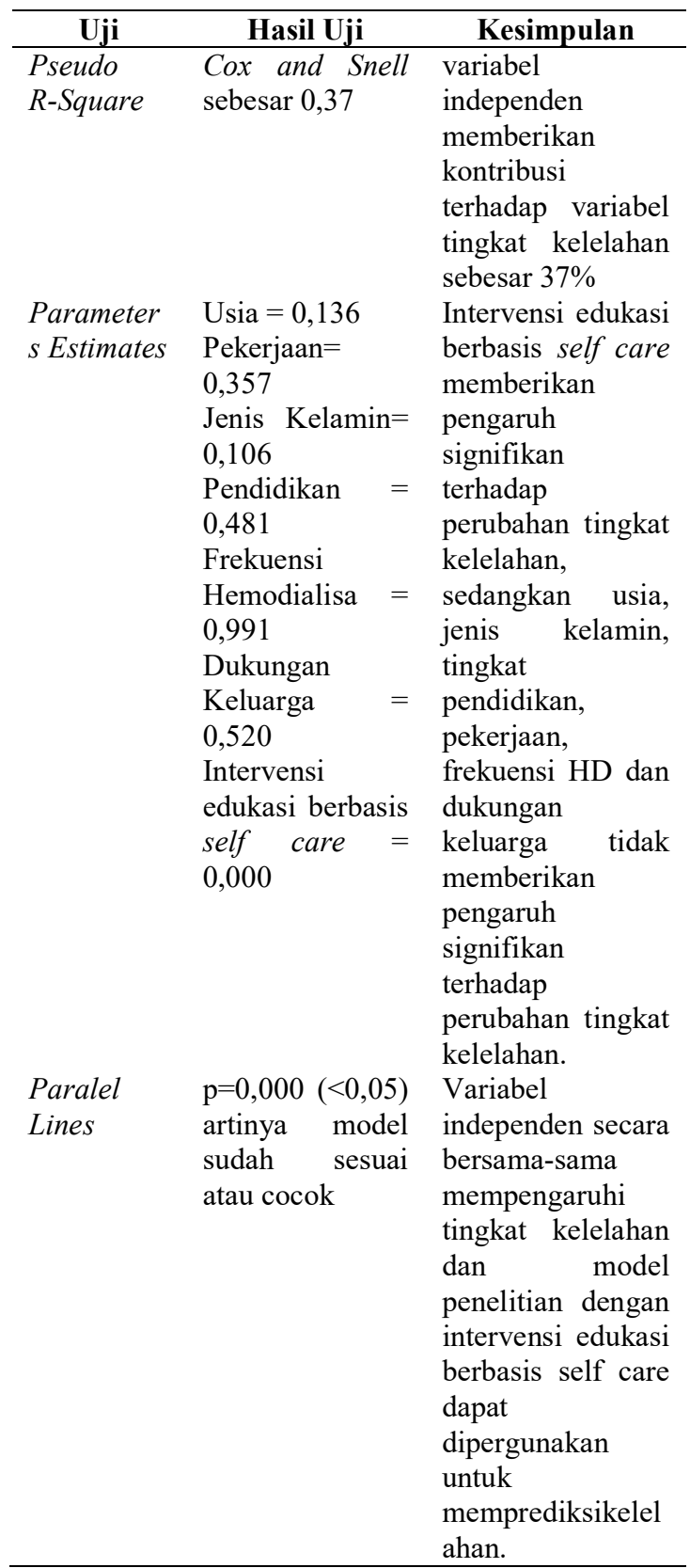

Hasil penelitian ini menujukkan distribusi mayoritas usia responden berada pada rentang usia 46 - 55 tahun, hal ini menunjukkan sebagian besar pasien CKD yang menjalani hemodialisa pada usia pertengahan yaitu sebanyak 54 orang (40,5\%). Penelitian ini berbeda dari apa yang disampaikan oleh (Seham et al., 2016) bahwa 86,70\% responden yang menjalani hemodialisa berusia $>60$ tahun, hal ini erat kaitannya dengan teori Smeltzare \& Bare (2010) mengatakan fungsi renal dan traktus urinarius akan berubah bersamaan dengan pertambahan usia. Setelah usia 40 tahun akan terjadi penurunan laju filtrasi glomerulus secara progresif hingga usia 70 tahun, kurang 50\% dari normalnya. Fungsi tubulus termasuk kemampuan reabsorbsi dan pemekatan juga berkurang bersamaan dengan pertambahan usia. Penelitian (Mohamed, 2014) memaparkan insiden tertinggi berada pada range usia $41-55$ tahun (75\%), data ini dikuatkan oleh National Kidney Foundation (2012) yang menyatakan di Amerika Serikat lebih dari dari 26 juta orang atau 13\% dari populasi orang dewasa mengalami Chronic Kidney Disease yang menjalani hemodialisa, sedangkan di Indonesia menurut data Riset Kesehatan Dasar (2013) terjadi peningkatan yang signifikan jumlah penderita dari tahun 2011 ke 2012 yaitu tercatat 22.304 penderita menjadi 28.782 dengan prevalensi pada kelompok usia 35-44 (0,3\%), usia 45-54 $(0,4 \%)$ dan usia 55-74 (0.5\%). Sintesa peneliti insiden tertinggi pada kelompok usia pertengahan dipengaruhi oleh perubahan fungsi renal dan traktus urinarius yang terjadi setelah usia 40 tahun, dimana terjadi penurunan laju filtrasi glomerulus secara progresif hingga usia 70 tahun, kurang 50\% dari normalnya. Selain itu juga erat hubungannya dengan pola hidup dan pola makan yang tidak sehat saat usia muda seperti mengkonsumsi makanan cepat saji, kesibukan 
Mahakam Nursing Journal Vol 2, No. 4, November 2018 : 141-150

yang membuat stress, duduk seharian di kantor, sering minum kopi dan minuman berenergi, jarang mengkonsumsi air putih. Tingginya insiden pada usia pertengahan dalam penelitian ini, berbeda dengan dari beberapa penelitian, hal ini terkait dengan secara fisiologis terjadi penurunan laju filtrasi glomerulus secara progresif hingga usia 70 tahun ditambah dengan menjalani hemodialisa, membuat kondisi pasien yang dialami semakin kompleks, berbagai komplikasi membuat kondisi pasien semakin menurun. Pada penelitian ini memiliki beberapa kriteria inklusi dalam memilih responden, kondisi pasien dengan komplikasi akan membuat pasien masuk dalam kriteria ekslusi.

Dalam penelitian ini menunjukan bahwa jenis kelamin responden mayoritas sebanyak 63 orang $(56,8 \%)$ adalah perempuan. Penelitian ini berbeda dari apa yang diungkapkan oleh Ganong (2012) yaitu lakilaki jauh lebih beresiko terkena penyakit gagal ginjal kronik daripada perempuan, dikarenakan perempuan mempunyai hormon estrogen lebih banyak. Hormon estrogen berfungsi untuk menghambat pembentukan cytokin tertentu untuk menghambat osteoklas agar tidak berlebihan menyerap tulang, sehingga kadar kalsium seimbang. Kalsium memiliki efek protektik dengan mencegah penyerapan oksalat yang bisa membentuk batu ginjal sebagai salah satu penyebab terjadinya gagal ginjal kronik. Sedangkan pada laki - laki dikaitkandengan gaya hidup yang kurang baik seperti merokok, alkohol, bergadang, kurangminum air, kurang olah raga dan banyak makanmakanan cepat saji. Faktor lain yang menyebabkan laki - laki lebih berisiko adalah bentuk anatomi saluran kemih pada laki - laki yang lebih panjang dibandingkan wanita, hal ini akan mengakibatkan pengendapan zat - zat yang terkandung dalam urine lebih banyak daripada wanita. Adanya pengendapan zat tersebut dalam waktu lama dapat menyebabkan terbentuknya batu saluran kemih, yang jika tidak ditangani dengan segera dan tepat akan mengganggu funsi ginjal. Gangguan funsi ginjal yang progresif pada akhirnya menyebabkan CKD dan harus menjalani hemodialisa. Namun penelitian Salwa (2014) menyatakan $80 \%$ responden pada penelitiannya adalah berjenis kelamin perempuan. Senada dengan penelitian (Ghadam et al., 2015) yang memaparkan pasien yang menjalani hemodialisa mayoritas berjenis kelamin perempuan sebanyak $56 \%$. Sintesis peneliti pada perempuan resiko mengalami infeksi saluran kencing lebih besar yang disebabkan anatomi saluran kemih wanita yang lebih pendek jika dibandingkan laki-laki, selain itu gaya hidup yang menyebabkan menderita diabetes melitus dan hipertensi memegang peranan yang tidak kalah besarnya.

Pada penelitian ini mayoritas responden yaitu sebanyak 47 orang (42,3\%) tidak bekerja. Hal ini berbeda dengan apa yang paparkan oleh Wijayanti (2016), yang 
Mahakam Nursing Journal Vol 2, No. 4, November 2018 : 141-150

menyatakan bahwa sebagian besar pasien yang menjalani hemodialisa masih bekerja yaitu $15 \%$ sebagai PNS, $25 \%$ swasta dan $60 \%$ sebagai petani. Namun dalam penelitian Mohammed (2014) yang memaparkan 45\% kelompok kontrol dan 50\% kelompok intervensi tidak bekerja. Smeltzer \& Bare (2010) memaparkan pasien yang menjalani hemodialisa akan mengalami sejumlah permasalahan dan komplikasi serta adanya perubahan pada bentuk dan fungsi sistem tubuh. Adanya sejumlah dampak ini tentunya akan mengganggu produktivitas yang dapat mengakibatkan seseorang kehilangan pekerjaan.

Dalam penelitian ini mayoritas responden memiliki tingkat pendidikan SMA/sederajat, pada kelompok intervensi yaitu sebanyak 48 orang $(57,8 \%)$, dan pada kelompok kontrol yaitu sebanyak 17 orang (60,7\%). Penelitian ini berbeda dari apa yang disampaikan oleh (Qobadi, Besharat, Rostami, \& Rahiminezhad, 2015) bahwa sebagian besar $(44,6 \%)$ pasien yang menjalani hemodialisa memiliki tingkat pendidikan rendah (SD), hal ini erat kaitannya dengan semakin rendah pendidikan responden maka semakin terbatas kemampuan dalam menyelesaikan masalah sehingga menimbulkan respon kecemasan. Hasil penelitian Tsiamis et al., (2015) menunjukkan prevalensi tingkat pendidikan pasien hemodialisa pada 134 responden yang diteliti adalah tingkat pendidikan menengah (SMA) yaitu sebanyak 64 orang (47,7\%). Penelitian Zyga (2015) memaparkan dari 138 responden tingkat pendidikan rata - rata menengah (SMA) 41,4\%. Penelitian Hermawati (2016) menunjukkan bahwa mayoritas pasien berada tingkat pendidikan menengah 51,7\%, hal ini menurut Azwar (2013) semakin tinggi tingkat pendidikan seseorang maka dia akan cenderung untuk berperilaku positif karena dari pendidikan yang diperoleh dapat meletakkan dasar pemahaman dan perilaku dalam diri seseorang. Di dukung oleh pernyataan Anees et al., (2014) bahwa tingkat pendidikan yang tinggi akan lebih mudah dalam mengidentifikasi stressor dalam diri sendiri maupun dari luar dirinya, tingkat pendidikan juga mempengaruhi kesadaran dan pemahaman terhadap stimulus.

Penelitian ini menunjukan mayoritas responden yaitu sebanyak 99 orang $(89,2 \%)$ menjalani hemodialisa $2 \times$ seminggu. Pernefri (2013) mengatakan frekuensi hemodialisa disesuaikan dengan kebutuhan individu, tergantung pada derajat kerusakan ginjal, diet sehari - hari dan penyakit lain yang menyertai. Penelitian Alwer (2013) memaparkan bahwa jarak hari pasien menjalani hemodialisa mempengaruhi kapasitas fungsional dan persepsi pasien tentang kesehatan generalnya terkait dengan perawatan diri.

Penelitian ini memaparkan mayoritas responden mendapat dukungan dan didampingi oleh keluarga yaitu sebanyak 98 orang $(88,3 \%)$. Dukungan yang diberikan ini berupa menemani saat menjalani hemodialisa 
Mahakam Nursing Journal Vol 2, No. 4, November 2018 : 141-150

dan selalu memberikan dukung baik secara moril maupun materi. Penelitian Steinhauser et al., (2010) yang memaparkan bahwa dukungan keluarga berperan penting dalam proses medikasi pasien. Penelitian Suryaningsih (2013) mengemukakan adanya hubungan antara dukungan keluarga dengan kecemasan pada pasien CKD diruang hemodialisa. Penelitian (Wang et al., 2016) memaparkan bahwa pada 173 responden yang diteliti dukungan keluarga yang diberikan sangat besar manfaatnya untuk membantu meningkatkan fungsi kognitif, dengan nilai $p=0,022$. Sintesa peneliti dukungan keluarga sangat bermanfat dalam proses adaptasi pada pasien yang menjalani hemodialisa, karena dukungan yang diberikan keluarga meningkatkan rasa kepercayaan diri dan optimisme pasien serta harga diri dan nilai sosial pada diri pasien, sehingga merasa dirinya penting dan dicintai.

Penelitian ini menunjukkan 3 keluhan kelelahan yang paling menonjol dialami oleh pasien, yaitukecewa dan kesal karena terlalu lelah untuk melakukan apapun yang ingin dilakukan, keluhan sulit memulai apapun karena lelah dan keluhan seluruh tubuh terasa lemah. Sintesa peneliti proses terapi hemodialisis yang membutuhkan waktu 4-5 jam dengan frekuensi $2 \mathrm{x}$ seminggu, umumnya akan menimbulkan stress fisik pada pasien. Manifestasi kelelahan merupakan rasa lelah yang menetap dan bertambah parah hal inilah yang menimbulkan rasa kecewa dan kesal karena terlalu lelah untuk melakukan apapun yang ingin dilakukan. Kemudian keluhan tubuh terasa lemah dan sulit memulai apapun karena lelah.

Perubahan kelelahan responden sebelum intervensi edukasi berbasis self care mayoritas di tingkat berat yaitu 83 responden $(100 \%)$. Setelah diberikan intervensi edukasi berbasis self carekeluhan menurun menjadikelelahan ringan dengan jumlah mayoritas 70 responden $(83,4 \%)$. Penelitian (Han \& Kim, 2015)memaparkan bahwa ada peningkatan keluhan kelelahan yang signifikan setelah pasien menjalani terapi dialisis dan hal ini dianggap sebagai isu yang penting pada pasien hemodialisa.Penelitian meta analisis Asano et al., (2014) pada 338 responden menyimpulkan intervensi edukasi yang diberikan pada pasien dengan keluhan kelelahan sangat membantu dalam mengurangi keluhan yang dirasakan, dengan tingkat signifikan penelitian $p<0,001$. Penelitian Tzu-Chieh et al., (2015) memaparkan edukasi dan panduan self care yang diberikan sangat bermanfaat dalam menurunkan keluhan kelelahan. Penelitian Patricia (2017) memaparkan edukasi tentang strategi self care yang meliputi latihan fisik, istirahat dan relaksasi untuk mengatasi kelelahan sangat signifikan dalam menurunkan keluhan tersebut $(p=0,012)$. Hasil yang diharapkan dari suatu edukasi kesehatan adalah perilaku kesehatan, atau perilaku untuk memelihara dan meningkatkan kesehatan yang kondusif oleh sasaran dari promosi kesehatan. (Notoadmojo, 2012). 
Mahakam Nursing Journal Vol 2, No. 4, November 2018 : 141-150

Sintesa peneliti edukasi self care yang diberikan selama 6 minggu sangat memberikan dampak besar terhadap tingkat kelelahan yang dialami oleh pasien terutama pada keluhan kecewa dan kesal karena terlalu lelah untuk melakukan apapun yang ingin dilakukan, kemudian keluhan sulit memulai apapun karena lelah, dan keluhan seluruh tubuh terasa lemah, hal ini nampak dari nilai p-value $0,000 \quad(<0,05)$ yang menunjukkan tingkat signifikan intervensi edukasi berbasis self care. Edukasi yang diberikan berpengaruh terhadap perubahan pengetahuan, perubahan sikap dan tindakan dari pasien untuk menuju ke arah perilaku yang lebih positif sehingga tingkat kelelahan dapat menurun. Edukasi berbasis self care yang diberikan memberikan perubahan yang sangat signifikan terhadap tingkat kelelahan yang dirasakan, hal ini erat kaitan dengan metode kombinasi yang dilakukan yang tidak sama seperti edukasi pada umumnya. Edukasi berbasis self care diberikan dengan metode kombinasi video dan booklet sehingga responden tidak hanya mendengar tetapi juga dapat langsung melihat dan melakukan langsung latihan fisik yang dianjurkan dalam edukasi berbasis self care ini. Materi ini dikemas dengan booklet yang simple dan video sehingga selain mendapatkan informasi dari rumah sakit, responden dapat membawa pulang dan membaca serta menonton video dirumah dengan demikian kemungkinan retensi informasi yang diberikan dapat berlangsung lama.
Penelitian (Georgios, Victoria, \& Evangelos, 2015) memaparkan semakin rendah tingkat pendidikan responden maka semakin besar keluhan kelelahan yang dilaporkan, namun dalam penelitian ini didapatkan data bahwa mayoritas responden yaitu sebanyak 65 orang $(58,6 \%)$ memiliki tingkat pendidikan SMA dan Pendidikan Tinggi, hal ini menurut Azwar (2005) semakin tinggi tingkat pendidikan seseorang maka dia akan cenderung untuk berperilaku positif karena dari pendidikan yang diperoleh dapat meletakkan dasar pemahaman dan perilaku dalam diri seseorang. Sintesa peneliti pengetahuan adalah hal penting dalam membentuk tindakan seseorang, oleh karena itu dengan tingginya tingkat pendidikan diharapkan juga akan meningkatkan pengetahuan pasien dan akan menumbuhkan kesadaran untuk mencari pengobatan dan perawatan terhadap masalah kesehatan yang dihadapinya.

\section{SIMPULAN}

Hasil dari penelitian ini memaparkan adanya pengaruh edukasi berbasis self care terhadap perubahan tingkat kelelahan, hal ini sangat erat kaitannya dengan metode yang dilakukan. Edukasi berbasis self care diberikan dengan metode kombinasi video dan booklet sehingga responden tidak hanya mendengar tetapi juga dapat langsung melihat dan melakukan langsung latihan fisik yang dianjurkan. Materi ini dikemas dengan booklet yang simple dan video sehingga selain mendapatkan informasi dari rumah 
Mahakam Nursing Journal Vol 2, No. 4, November 2018 : 141-150

sakit, responden dapat membawa pulang dan membaca serta menonton video dirumah dengan demikian kemungkinan retensi informasi yang diberikan dapat berlangsung lama. Merujuk pada karakteristik tingkat pendidikan responden mayoritas jenjang pendidikan menengah (SMA), sangat membantu tercapainya tujuan dari penelitian karena semakin tinggi tingkat pengetahuan maka analisis dan aplikasi terhadap informasi yang diberikan dapat maksimal

\section{UCAPAN TERIMA KASIH}

1. Ketua Yayasan Setia Budi Samarinda yang memberikan arahan dan dorongan untuk melakukan penelitian ini

2. Direktur Akper Dirgahayu untuk dukungan dalam penelitian ini

3. Ketua UPPM atas arahan dalam pengajuan proposal sampai penyelesaian laporan penelitian.

\section{DAFTAR PUSTAKA}

Alligood, M. R., (2014). Nursing Theorists and Their Work. St. Louis: Elsevier.

Badan Penelitian dan Pengembangan Kesehatan RI. (2013). Laporan Hasil RisetKesehatan Dasar (Riskesdas) Indonesia Tahun 2013.Jakarta: KementrianKesehatan Republik Indonesia.

Georgios, Tsiamis, et al.(2015). Assessment Of Quality of Life And Fatigue Among Haemodialysis Patients. American Journal of Nursing Science, 4(2-1): 66-73.
Ghadam, M.Sabet., Poorgholami, Farzad., Jahromi, Z.Badiyepeymaie., Parandavar, Nehleh., Kalani, Navid \& Rahmanian, Elham.(2016). Effect of Self-Care Education by Face-to-Face Method on the Quality of Life in Hemodialysis Patients. Global Journal of Health Science, 8, (6).

Han, Su-Jeong., \&Kim, Hye-Won. (2015). Post-dialysis Fatigue in Hemodialysis Patients.Healthcare and Nursing Journal ,104:180-183.

WHO. (2014). Global Prevelance Of Chronic Kidney

Disease.www.who.int/vmnis/pdf.

Diakses 30 september 2016.

Jahromi, M.Kargar., Poorgholami, Farzad., Javadpour, Shohreh \& Saadatmand, Vahid.(2016). Effectiveness of SelfCare Education on the Enhancement of theSelf-Esteem of Patients Undergoing Hemodialysis.Global Journal of Health Science, 8 (2).

Jhamb, Manisha, Weisbord, Steven. D., \& Unruh, Mark. (2008). Fatigue in patients Receiving Maintenance Dialysis : A review of Definitions, Measures, and Contributing Factor. Am J kidney Dis, 52(2).353.

Mohamed, Salwa.A.(2014).The Effectiveness of an Educational Intervention on Fatigue in Hemodialysis Patients: A Randomized Controlled Trial. Journal of Nursing and Health Science, 3: 4050. 
Mahakam Nursing Journal Vol 2, No. 4, November 2018 : 141-150

National Kidney Foundation. (2016). K/DOQI

Clinical Practice Guidelines

forChronic Kidney Disease:

Evaluation, Clasification and

Stratification.Diakses dari:

http://doi.org/10.1634/theoncologist.2

016-S2-45. Diakses 30 Oktober 2016.

Notoatmodjo, S. (2012).Pendidikan dan

Perilaku Kesehatan. Jakarta: Rineka

Cipta.

Parvan, Kobra., Hasankhani, Hadi., Seyyedrasooli, Allehe., Riahi, Seyed

Mohammad., \& Ghorbani, Mahmoud.

(2015).The Effect of Two Educational

Methods on Knowledge and

Adherence to Treatment in

Hemodialysis Patients: Clinical Trial.

Journal of Caring Sciences, 4(1), 83-

93.

Poorgholami, Farzad., Mansoori, Parisa.,

Montaseri, Zohreh \& Najafi,

Kazem.(2015). Effect of Self Care

Education with and withoutTelephone

Follow-Up on the Level of Hopein

Renal Dialysis Patients: A Single-

BlindRandomized Controlled Clinical

Trial. IJCBNM, 4(3):256-264.

Rostami, Fatemeh., Ramezani, B.F., \&Falah, N. (2015). A survey of the Impact of using Orem self-care model on Adequacy of Dialysis in Hemodialysis Patients. Bulletin of Environment, Pharmacology and Life Sciences, 4 (5): 19-23.
Smeltzer., \& Suzanne, C. (2012). Textbook Medical Surgical Nursing Brunner\&Suddarth (ed 13th). China: Lisa McAllister.

Wang, Si-Yuan., Zang, Xiao-Ying., Fu, Sheng-Hui., Bai, Jinbing., Liu, JunDuo., Tian, Li., Feng, Yu-Ying., \& Yue Zhao. (2016). Factors Related To Fatigue In Chinese Patients With EndStage Renal Disease Receiving Maintenance Hemodialysis: A MultiCenter Cross-Sectional Study. University North Carolina : DOI, 10.3109/0886022X.2016.1138819.

Zyga, Sofia., Alikari, Victoria., Sachlas, Athanasios., Fradelos, E.C., Stathoulis, John., Panoutsopoulos, Georgios., Georgopoulou, Maria., Theophilou, Paraskeui., \& Lavdaniti, Maria. (2015). Assessment of Fatigue in End Stage Renal Disease Patients Undergoing Hemodialysis:Prevalence and AssociatedFactors. Med Arh, 69(6): 376-380. 